\title{
Dermoid cyst of the greater omentum: rare and innocent?
}

\author{
Rutger M Schols, Laurents P Stassen, Kristien B Keymeulen, Nicole D Bouvy
}

Department of Surgery, Maastricht University Medical Center, Maastricht, The Netherlands

\section{Correspondence to}

Dr Rutger M Schols, rutgermschols@hotmail.com

\section{DESCRIPTION}

An 83-year-old woman presented with decreased appetite and weight loss. Upon physical examination a palpable swelling in the lower abdomen was detected. The radiologist was consulted regarding the possible presence of a malignancy.

A CT showed a bilobar mass located centrally in the pelvis, consisting of a cystic and solid component with a peel-shaped calcification and a maximum diameter of $9.2 \mathrm{~cm}$ (see figure 1).

Differential diagnosis: a degenerative leiomyoma of the uterus or a dermoid cyst of the right adnexa, presumably corresponding to the findings of the physical examination.

Furthermore, CT revealed an obstructing tumour in the transverse colon located at the splenic flexure.

Biopsy during colonoscopy revealed an intramucosal adenocarcinoma $55 \mathrm{~cm}$ ab ano, with focal
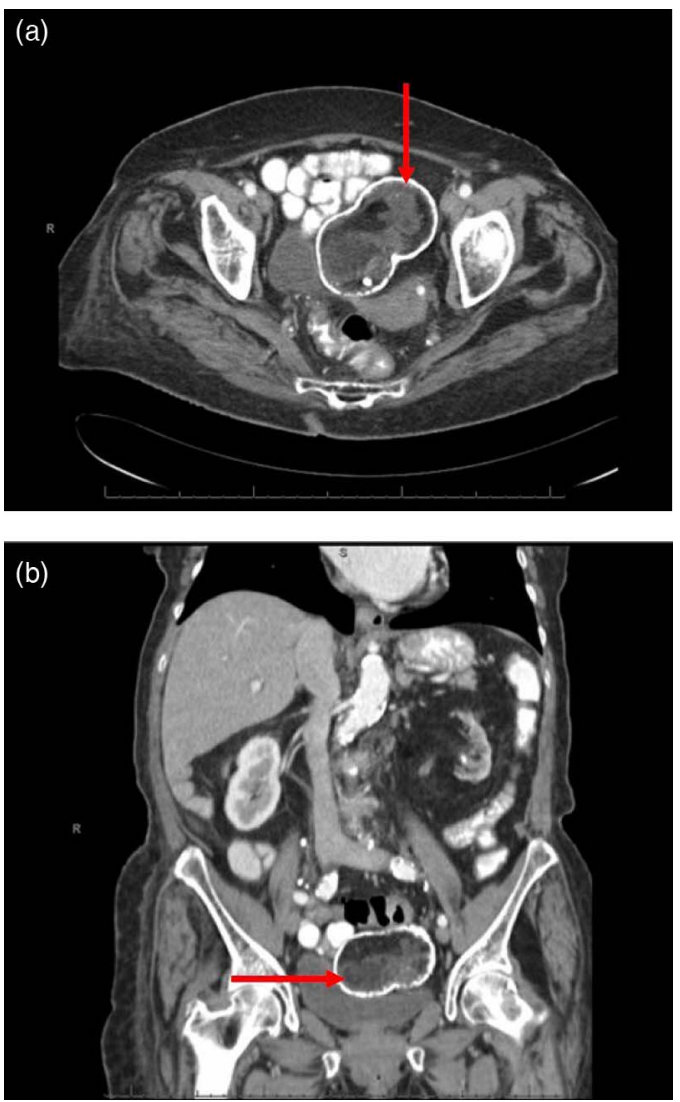

Figure 1 Transverse (A) and coronal (B) CT images: a bilobar mass (maximum diameter $9.2 \mathrm{~cm}$ ) is located centrally in the pelvis, consisting of a cystic and a solid component, with a peel-shaped calcification. suspected invasive growth. It was decided to perform a transverse colectomy.

Right at the beginning of the surgery a $10 \mathrm{~cm}$ large calcified sphere was found connected to the greater omentum and was resected (see figure 2).

Histological examination of the excised tissue from the omentum revealed a cyst of $179.5 \mathrm{~g}$ and dimensions of $9.5 \times 6 \times 5.5 \mathrm{~cm}$, with a fibrous wall filled with an amorphous material, calcification and hair. The pathologist's conclusion was the diagnosis of a rare dermoid cyst of the greater omentum; there were no signs of malignancy.

Dermoid cysts (mature cystic teratomas) of the omentum rarely occur. Usually these arise in the ovary. ${ }^{1}$ The diagnosis can be achieved by ultrasound and on CT. The exact localisation of the tumour is however extremely difficult. ${ }^{2}$ Potential malignant degeneration has to be considered, but is infrequent. ${ }^{3}$ Resection is the treatment of choice. Nevertheless, advanced age of the patient, absence of symptoms and a very low risk of malignant degeneration can be reasons for not performing surgery.

\section{Learning points}

- The occurrence of a dermoid cyst of the greater omentum is very rare.

- Possible malignant degeneration is not frequent, but has to be considered.

- Resection is the treatment of choice.

Competing interests None.

Patient consent Obtained.

Provenance and peer review Not commissioned; externally pee reviewed.

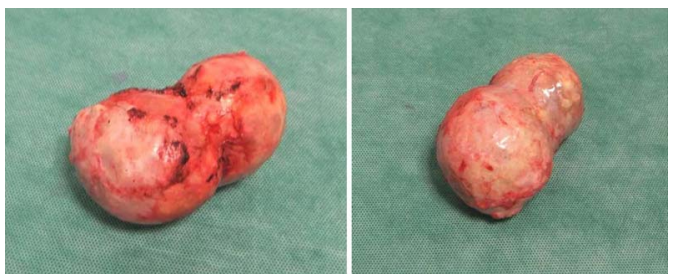

Figure 2 These pictures show the excised calcified sphere from the omentum of $179.5 \mathrm{~g}$ and dimensions of $9.5 \times 6 \times 5.5 \mathrm{~cm}$. 


\section{REFERENCES}

1 Yoshida A, Murabayashi N, Shiozaki T, et al. Case of mature cystic teratoma of the greater omentum misdiagnosed as ovarian cyst. J Obstet Gynaecol Res 2005;31:399-403.

2 Ushakov FB, Meirow D, Prus D, et al. Parasitic ovarian dermoid tumor of the omentum-a review of the literature and report of two new cases. Eur J Obstet Gynecol Reprod Biol 1998;81:77-82.

Copyright 2013 BMJ Publishing Group. All rights reserved. For permission to reuse any of this content visit http://group.bmj.com/group/rights-licensing/permissions.

BMJ Case Report Fellows may re-use this article for personal use and teaching without any further permission.

Become a Fellow of BMJ Case Reports today and you can:

- Submit as many cases as you like

- Enjoy fast sympathetic peer review and rapid publication of accepted articles

- Access all the published articles

Re-use any of the published material for personal use and teaching without further permission

For information on Institutional Fellowships contact consortiasales@bmjgroup.com

Visit casereports.bmj.com for more articles like this and to become a Fellow
3 Kubosawa $\mathrm{H}$, Iwasaki $\mathrm{H}$, Kuzuta $\mathrm{N}$, et al. Adenocarcinoma with peritoneal dissemination secondary to multiple mature teratomas of the omentum. Gynecol Oncol 2006;101:534-6. 